\title{
Enjoying or Refraining from Risk? \\ The Impact of Implicit Need for Achievement and Risk Perception on SME Internationalization
}

\author{
Radityo Putro Handrito ${ }^{*}, 1,2,3$, Hendrik Slabbinck ${ }^{1}$, Johanna Vanderstraeten ${ }^{2}$ \\ * Corresponding author: radityo.handrito@ugent.be , radityohandrito@ub.ac.id \\ ${ }^{1}$ Ghent University, Belgium; ${ }^{2}$ University of Antwerp, Belgium; \\ ${ }^{3}$ Brawijaya University, Indonesia
}

Please cites this article as Handrito, R. P., Slabbinck, H., \& Vanderstraeten, J. (2020). Enjoying or refraining from risk? The impact of implicit need for achievement and risk perception on SME internationalization. Cross Cultural \& Strategic Management, ahead-of-print(ahead-of-print). doi:10.1108/ccsm-03-2019-0068

\begin{abstract}
Purpose: This study explores how an entrepreneur's implicit need for achievement and its risk reception contribute to internationalization performance.

Design: This study involves 176 Indonesian entrepreneurs. We use the Operant Motive Test (OMT) to assess the entrepreneur's implicit needs and apply hierarchical Tobit regression to assess the interplay between implicit need for achievement, risk perception, and internationalization. Finding: We show that an entrepreneur's basic needs and risk perception play an essential role in SME internationalization. More specifically, we reveal a positive association between the entrepreneur's need for achievement and SME internationalization. We also show a U-shaped relationship for the moderation effect of risk perception on this relationship. That is, for a high need for achievement motivated entrepreneurs, the level of internationalization is at the highest when risk perception is either very low or very high.

Originality/value: In this study, we argue that analyses at the entrepreneur's individual level are indispensable to better understand firm internationalization. We argue that the role of psycho-cognitive characteristics of individuals (such as motivational dispositions) received too little attention, compared
\end{abstract}


to factors at the firm or environmental level. This study examines such personality aspects; that is, the implicit need for achievement and risk perception, impact SME internationalization.

Keywords: Internationalization, Implicit Need for Achievement, Risk Perception, SEM, Operant Motive Test (OMT).

Paper type: Research paper

\section{Introduction}

Internationalization is a promising strategic option, both for small and large firms. It does not only allow a firm to expand its market, but also improves the firm's domestic competitive position to gain revenue as well as profitability (Brouthers, Nakos, \& Dimitratos, 2015; Johanson \& Vahlne, 1977; McDougall \& Oviatt, 2000). Next to such beneficial effects for the individual firm, internationalization is also advantageous for reducing unemployment (Al-Hyari, Al-Weshah, \& Alnsour, 2012), resulting in nation-wide economic development (Cavusgil \& Nevin, 1981; Da Rocha, Kury, \& Monteiro, 2009; George, Wiklund, \& Zahra, 2016). Therefore, scholars already studied firm internationalization for many decades. Even though past research mainly focussed on large well-established enterprises (Hitt, Hoskisson, \& Kim, 1997), the internationalization of small and medium enterprises (SMEs) gained significant and increasing attention in the last decades (Child et al., 2017; Child \& Hsieh, 2014; McDougall \& Oviatt, 2000).

Studies on SME internationalization are abundant. For example, differences in the SME's social networks and consolidation, value-adding, and disruption capabilities (Pinho \& Prange, 2016), structure, technology, and people (Lin, 1998), internal and external factors (Leonidou, 2004), and innovation (Dai, Maksimov, Gilbert, \& Fernhaber, 2014; Shan, Song, \& Ju, 2016) have been put forward as determinants of SME internationalization. Even though such studies shed light on the barriers of SME internationalization and considerable efforts have been undertaken to tackle these barriers and thus further stimulate SME internationalization (Al- 
Hyari et al., 2012; Caiazza, 2016; Cerrato, Crosato, \& Depperu, 2016; Etemad, 2004; Leonidou, 2004), the contribution of SMEs to international trade is still rather low (WTO, 2016). This urges us to search for additional explanations to better understand SME internationalization. In this paper, we argue that for this, we need to consider the entrepreneur's individual characteristics.

The reason that we focus on the individual level is twofold. First, the impact of the entrepreneur's personality on firm functioning is higher in small and medium firms than in large firms (Brammer, Hoejmose, \& Marchant, 2011; Child et al., 2017; Redmond, Walker, \& Wang, 2008). It thus makes sense to take into account the entrepreneur's personal characteristics in any study about SME internationalization. Second, and more importantly, even though research that focused on individual characteristics such as learning behavior (de Clercq, Sapienza, \& Crijns, 2005), the entrepreneur's competence (Chandler \& Hanks, 1994; Dimitratos, Buck, Fletcher, \& Li, 2016), cognition (Acedo \& Florin, 2006; Acedo \& Jones, 2007), personal drivers (Prange \& Pinho, 2017), personality traits (Omri \& Becuwe, 2014), and motivation (Dimitratos, Buck, et al., 2016), concluded that individual characteristics indeed play an important role in SME internationalization and performance, individual psychological characteristics (such as deep-level implicit motives) and their interplay with other individual characteristics (such as risk perception) have been largely overlooked (Ruzzier, Matlay, Hisrich, \& Antoncic, 2006; Westhead, Wright, \& Ucbasaran, 2001).

This is very unfortunate, in particular, because authors such as Frese and Gielnik (2014) argue that the entrepreneur's psychological needs might influence SME internationalization. Indeed, they call for additional and more in-depth insights into the entrepreneur's psychological needs to better understand the relation between the entrepreneur and international business performance. This need for additional studies about the entrepreneur's psychological needs is also apparent in review studies in the international entrepreneurship domain, such as those from 
Jones, Coviello, and Tang (2011), Knight and Liesch (2016), and Chen, Sousa, and He (2016), who all call for more insight into the relationship between an entrepreneur's psychological needs and international entrepreneurship.

To answer such please, we build on implicit needs theory (McClelland, Koestner, \& Weinberger, 1989) and examine the relationship between the entrepreneur's implicit need for achievement and SME internationalization. Implicit Need for Achievement, from now on referred to as $n$ Achievement ${ }^{1}$, is a deep-rooted motivation that energizes individuals to engage in challenging tasks to improve their performance or to improve their standards of excellence (McClelland, 1965a, 1985; Schultheiss \& Brunstein, 2010). In addition, risk-taking behaviors strongly determine if and to what extent $n$ Achievement motivated people will initiate and persist behavior (Pang, 2010), which is specifically relevant in an internationalization context, where risk is inextricably present (Acedo \& Florin, 2006; Acedo \& Jones, 2007; Johanson \& Vahlne, 2009; Prange \& Pinho, 2017). Therefore, in this study, we include both $n$ Achievement and risk perception of internationalization and argue for an interaction effect between these constructs. Because in our study, risk perception of internationalization is defined as an individual and subjective (or, in other words, personal) concept, adding this variable allows us to understand the interplay of two individual characteristics of the entrepreneur on firm internationalization: $n$ Achievement and risk perception (Muzychenko \& Liesch, 2015; Sitkin \& Weingart, 1995).

Overall, we focus on the entrepreneur's $n$ Achievement and risk perception for four reasons. First, $n$ Achievement is a significant driver of entrepreneurial activity (Collins, Hanges, \& Locke, 2004; McClelland, 1965a; Pang, 2010; Shane, Locke, \& Collins, 2003). Its impact on

\footnotetext{
${ }^{1}$ McClelland makes a clear distinction between implicit and explicit motives and refers to implicit motives as needs, abbreviated with a lower-case and an italic $n$ (McClelland et al, 1989). So far, the conceptual distinction between implicit and explicit motives is less pronounced in business and management research. Yet, because explicit and implicit motives are conceptually different and linked to different behavioral outcomes, we will follow the tradition in psychology and refer to implicit need for achievement as $n$ Achievment.
} 
SME internationalization, however, is largely unknown. We address this with our study. Second, because implicit motives, including $n$ Achievement, are specifically good in predicting long-term behaviors (Schüler, Sheldon, \& Fröhlich, 2010; Schultheiss \& Brunstein, 2010), we expect that $n$ Achievement impacts business decisions with long-term consequences such as internationalization. Third, the internationalization of SMEs is considered as a challenging task and achieved through a relatively-long term process (Chye Koh, 1996; Sagie \& Elizur, 1999; Schultheiss, Wiemers, \& Wolf, 2014). It thus makes sense to add both $n$ Achievement (which is a psychological construct expected to impact such long-term processes), ánd risk perception (which defines how challenging the task is perceived) to the conceptual model. Fourth and finally, $n$ Achievement is associated with risks and is channeled into the hope of success (HS) and fear of failure (FF) (Atkinson, 1957; Atkinson \& Litwin, 1960). That is, a person's inner hope for success stimulates the individual to take risks, to do everything that is needed to reach one's personal goals whereas the person's inner fear for failure withholds a person to take too much risk to safeguard the person's previous accomplishments (Atkinson, 1957; Atkinson \& Litwin, 1960; Clark, Teevan, \& Ricciuti, 1956; de Charms \& Dave, 1965). Again, because of the expected relationship between $n$ Achievement's sub-constructs with risk, and because studies from, e.g., Atkinson and colleagues indicate that implicit motives spontaneously direct entrepreneurs toward long-term effort-related and challenging tasks (such as, as we argue, internationalization), a focus on $n$ Achievement and risk perception is appropriate in a study about SME internationalization.

With this study, we provide two overarching contributions to literature and practice. First, we introduce human needs in general and $n$ Achievement in particular as a new determinant of SME internationalization, answering Frese and Gielnik's (2014) and Acedo and Jones's (2007) calls to explore personality aspects in internationalization research further. Indeed, by studying the psychological drivers of SME internationalization and the impact of 
risk perception of internationalization, our insight may help entrepreneurs to develop or select specific internationalization strategies that fit their personality profile and risk assessment of the chosen internationalization strategy. Furthermore, policymakers might develop specific support programs (such as coaching trajectories) to optimize the internationalization process, which ultimately may add to the growth and profitability of both the firm and the country's economic prosperity.

Our second contribution relates to our empirical setting. Research on SME internationalization is mostly focused on Western firms (Al-Hyari et al., 2012; Coviello \& Jones, 2004; Leonidou, 2004; Rialp, Rialp, \& Knight, 2005). Studies involving SMEs in developing countries are scarce and badly needed (Acs, Dana, \& Jones, 2003), in particular, because active internationalization opportunity-seeking is related to the welfare of developing countries (Che Senik, Scott-Ladd, Entrekin, \& Adham, 2011). To address the dearth of studies on SME internationalization in developing countries, we focus on Indonesia as our research setting. This economy grew considerably in the last couple of years, with a current GDP growth ranking $3^{\text {rd }}$ among BRIC and G20 Countries, a Global Competitiveness Index that increased from 54 in 2007 to 41 in 2016, and an increase of the Ease of Doing Business Index from 129 in 2015 to 91 in 2017 (Indrawati, 2017). Its economy is expected to further grow in the future, and the government commits to support export strengthening programs to achieve this growth (World-Bank, 2018). Given that in 2015, Indonesia had around 700.000 SMEs which contributed for 22 percent to the Gross National Product (Japhta, 2016) and SME growth reaches up to 8.4 percent with 10.6 percent growth in investment value between 2011 and 2015 (Bappenas, 2016), our research may provide new insights into the psychological determinants that may further support the international growth of SMEs in an emerging Asian economy. By doing so, our research also allows us to answer the question whether western-based theories such as Motive Disposition Theory (MDT), can be applied with the same ease across the world 
(Bruton \& Lau, 2008; Li \& Peng, 2008; Meyer, 2007; Meyer \& Peng, 2016; Peng, Bhagat, \& Chang, 2010).

\section{Literature Review and Hypotheses}

\subsection{The Personality of the Entrepreneur}

SMEs have a relatively informal and small organizational structure and are mostly managed by a single owner-manager (Bianchi \& Noci, 1998; Rauch, Frese, \& Utsch, 2005). As a result, the entrepreneur's personality significantly affects SME behavior (Brammer et al., 2011; Redmond et al., 2008) and this to a greater extent than in large enterprises (Miller \& Toulouse, 1986). Therefore, insights from the psychological aspects of the entrepreneur are needed to understand the relationship between entrepreneurs and business performance (Frese \& Gielnik, 2014). Indeed, the entrepreneur's personality characteristics such as skills, education, competencies, experiences, commitments, and strong internationalization motivations impact the decision to internationalize (Child \& Hsieh, 2014), the internationalization process (Amorós, Basco, \& Romaní, 2014; Bradley, McMullen, Artz, \& Simiyu, 2012; Javalgi \& Todd, 2011; Shane \& Venkataraman, 2000; Unger, Rauch, Frese, \& Rosenbusch, 2011), and internationalization performance (Child et al., 2017; Jones et al., 2011; Terjesen, Hessels, \& Li, 2016).

Despite such initial evidence and on-going calls for more research on individual internationalization drivers (Acedo \& Jones, 2007; Cavusgil \& Nevin, 1981; WiedersheimPaul, Olson, \& Welch, 1978), to date, studies explicitly exploring the relationship between the personality of the entrepreneur and SME internationalization are scarce (Jones et al., 2011; Knight \& Liesch, 2016). For example, Wiedersheim-Paul et al. (1978) stress that at the start of the internationalization process, the personal characteristics of the decision-maker are relatively more important than the characteristics of the firm and its environment. In a subsequent study, 
Cavusgil and Nevin (1981) show that the entrepreneur's aspirations, expectations, and commitments account for a substantial portion of the variation in the firm's internationalization process.

Such early studies inspired a small community of recent scholars to further investigate the impact of the entrepreneur's individual characteristics on her/his internationalization efforts (Dimitratos, Buck, et al., 2016). Even though it has been suggested that the entrepreneur's personality can address financial and organizational barriers hindering SME internationalization (Prange \& Pinho, 2017), previous research did not widely explore, nor did it pay much attention to the entrepreneur's psychological characteristic to better understand SME internationalization efforts (Jones et al., 2011; Knight \& Liesch, 2016).

This gap in the literature limits our ability to understand why and how entrepreneurs achieve internationalization while overcoming various challenges associated with operating in multiple country contexts. To fill this gap, we theorize on the dynamics between a specific psychological construct; the implicit need for achievement (nAchievement) and SME internationalization. $n$ Achievement proved to be related to entrepreneurial behavior, decisionmaking behavior, managerial ability, and business performance (McClelland, 1961, 1965a; Pang, 2010; Pang, Villacorta, Chin, \& Morrison, 2009; Slabbinck et al., 2018; Winter, 2010).

Moreover, $n$ Achievement is of particular interest in the context of SMEs because successful founder-managers in SMEs have distinctly different personality profiles than the successful managers of established, larger organizations (Ling, Zhao, \& Baron, 2007). Indeed, successful SME owners are characterized by a relatively high level of $n$ Achievement (Johnson, 1990; Unger, Rauch, Weis, \& Frese, 2015). In a similar vein, McClelland (1965a) showed that $n$ Achievement predicted both individual entrepreneurial activity and success, while $n$ Achievement did not predict success in other career domains. Comparing entrepreneurs with corporate managers, Stewart Jr, Watson, Carland, and Carland (1999) showed that 
entrepreneurs score significantly higher on $n$ Achievement than corporate managers. Finally, McClelland (1961) also provided evidence that societal-level $n$ Achievement predicted national entrepreneurial activity and Andrews (1967) found that college students scoring more highly in $n$ Achievement are more entrepreneurial than low scorers. More recently, a meta-analysis (Collins, Hanges, and Locke, 2004) supported this idea.

\subsection{Human Needs and Internationalization}

Human needs theory does not only discuss the existence of personal motives but also distinguishes between explicit and implicit motives (McClelland et al., 1989). Explicit motives involve controlled or conscious information processing and propositional reasoning, while implicit motives concern automatic or non-conscious information processing (McClelland et al., 1989; Schultheiss \& Brunstein, 2010; Slabbinck et al., 2018). Importantly, explicit and implicit motives operate independently from each other; each of them influencing different behaviors (Kollner \& Schultheiss, 2014; Perugini, Richetin, \& Zogmaister, 2010). That is, explicit motives predict immediate and short-term behavioral responses that are subject to conscious thoughts and deliberations including self-reflective appraisals, judgment of others, and deliberate choices, whereas implicit motives predict stable, long-term, and spontaneous effort-related task performance, (Perugini et al., 2010; Schüler et al., 2010; Schultheiss \& Brunstein, 2010).

Human needs theory (McClelland, 1985; McClelland et al., 1989) assumes that people initiate and persist behavior that provides satisfaction as well as behavior that prevents dissatisfactions and disappointments. Basic human needs are formed in early life through (prelinguistic) affection learning experience (Schultheiss \& Kollner, 2014; Schultheiss \& Schultheiss, 2014; Weinberger \& McClelland, 1990). For example, if a toddler gets its own cutlery and is continuously stimulated to eat without any help, regardless of the mess (s)he 
makes, (s)he is more likely to develop a high need to work and act independently (McClelland \& Pilon, 1983). Hence, because of this positive affective learning experience, that person is in its later life more likely to react automatically and more favorably to the situation that calls upon her/his capacity to act and work autonomously (McClelland et al., 1989).

Because internationalization is a process or a decision with long-term consequences (Johanson \& Vahlne, 1977) and because performance on the international market is largely effort-related, we focus on implicit motives rather than on explicit motives (Bernecker \& Job, 2010; Schultheiss \& Brunstein, 2001; Slabbinck, De Houwer, \& Van Kenhove, 2011). Moreover, behavior that provides true satisfaction is mostly driven by the unconscious; implicit needs (Palmer, 1971; Schüler et al., 2010). In addition, previous studies almost exclusively based on explicit motives and drivers of internationalization (Dimitratos, Johnson, Plakoyiannaki, \& Young, 2016; Shane et al., 2003). Because of a lack of consensus about the impact of such explicit measures on internationalization, research is ready to expand toward the examination of implicit antecedents.

As argued, in this paper, we focus on the implicit need for achievement ( $n$ Achievement) (McClelland et al., 1989; Schultheiss \& Brunstein, 2010). nAchievement is a motivation that energizes individuals to engage in challenging tasks to improve their performance or to improve their standards of excellence (Ahmed, 1985; Litwin, 1966; McClelland, 1965a; Schultheiss \& Brunstein, 2010; Touhey \& Villemez, 1975). A vast number of studies showed that, compared to people with a low $n$ Achievement, high $n$ Achievement people show greater devotion to challenging tasks and report greater satisfaction after completion of these tasks. $n$ Achievement also motivates people to work independently and to be responsible for their own performance (Atkinson \& Litwin, 1960; de Charms \& Carpenter, 1968; Litwin, 1966; McClelland, Atkinson, Clark, \& Lowell, 1953; McClelland, Clark, Roby, \& Atkinson, 1949). 
Interestingly, $n$ Achievement has been linked to business performance and entrepreneurial activity in general (Collins, Locke, \& Hanges, 2000) and consistently proved to be the determinant of entrepreneurial success in entrepreneurship literature (Chye Koh, 1996; Westhead, Ucbasaran, \& Wright, 2005). For example, McClelland (1965a) shows that students high in $n$ Achievement are more likely to pursue an entrepreneurial occupation in the future, and Robinson, Huefner, and Hunt (1991) show that entrepreneurs have a higher level of $n$ Achievement compared to non-entrepreneurs.

Recently, Slabbinck et al. (2018) demonstrate that start-ups grow faster when achievement-motivated entrepreneurs manage them. Also, to master challenges such as internationalization; persistence and a strong desire to improve one standard of excellence are required, which fits well with $n$ Achievement motivated entrepreneurs (Atkinson \& Litwin, 1960; Feather, 1963; McClelland, 1985; Pang, 2010). Furthermore, because internationalization is seen as a learning process that challenges entrepreneurs to discover, evaluate, and exploit business opportunities (Johanson \& Vahlne, 1977; Kauppinen \& Juho, 2012; Oviatt \& McDougall, 2005), and entering the international market is followed by significant challenges (Shrader, Oviatt, \& McDougall, 2000), we argue that scoring highly on $n$ Achievement plays a vital role in SME internationalization. Hence, we hypothesize:

H1: SMEs governed by high $n$ Achievement motivated entrepreneurs portray a higher level of internationalization.

\subsection{Human Needs and Internationalization Risks}

Implicit motives do not operate in a vacuum. Personality psychologists have long argued that deliberative thoughts and considerations such as individual perceptions channel the expression of implicit motives such that both interact in the prediction of relevant outcome variables (Bing et al., 2007; Lang, Zettler, Ewen, \& Hülsheger, 2012; Winter, John, Stewart, 
Klohnen, \& Duncan, 1998). Thus, a high implicit motive is consequently most strongly expressed in behavior when the person also has a compatible level of functionally related deliberative thoughts and considerations.

The extent to which an entrepreneur perceives the internationalization of her/his SME as a risky business activity is most likely such a compatible deliberative process. Internationalization is an entrepreneurial act during which risk-taking dominates (McDougall \& Oviatt, 2000). Because of the broadening of the business scope, especially across national borders, internationalization is characterized by higher levels of risk and uncertainty (Figueira de Lemos, Johanson, \& Vahlne, 2011; Jones \& Covielo, 2005; Oviatt \& McDougall, 1994; Yamakawa, Peng, \& Deeds, 2008). Due to their limited scale and resources, SMEs face liabilities of foreignness and experience difficulties in mitigating such internationalization risks (Oparaocha, 2015). Indeed, lack of knowledge, cultural differences, language barriers, differences in economic policies and regulation, and complex logistics processes are all sources of risk and uncertainty that are inherently connected to a business crossing geographical boundaries (Knight \& Cavusgil, 2004; Ruzzier et al., 2006; Welch \& Luostarinen, 1988). Acedo and Jones (2007) show that entrepreneurs with low-risk perceptions tend to expand their internationalization activities faster than entrepreneurs with high-risk perceptions.

Interestingly, risk-taking behavior is also linked to $n$ Achievement (Ahmed, 1985; Atkinson, 1957; Brody, 1963; McClelland \& Watson, 1973; Ryan, Tipu, \& Zeffane, 2011). Sagie and Elizur (1999), for example, found that $n$ Achievement motivated people are more willing to face risks and uncertain situations such as the establishment of new ventures. Risk perceptions of behaviors also strongly determine if and to what extent $n$ Achievement motivated people will initiate and persist these behaviors (Pang, 2010). As explained earlier, achievement motivated people prefer challenging tasks (McClelland, 1985). An important nuance here is that challenging is not identical to risky. 
More specifically, Expectancy-Value Theory (Atkinson, 1957; Cooper, 1983; Spangler, 1992) argues that $n$ Achievement motivated people perceive tasks and behaviors that are associated with moderate risk levels as the most challenging. nAchievement motivated individuals will not engage in tasks with low perceived risks because the execution of these tasks will neither improve their skills nor their level of performance (Brunstein \& Schmitt, 2004; Cooper, 1983). Similar reasoning holds for tasks and behaviors that are considered as very risky: If the perceived likelihood of failure is too high or if the task is considered as too difficult, the task is no longer challenging (de Charms \& Dave, 1965; Nicholls, 1984) because the outcome of the task, i.e. failure, is highly predictable. Thus, the likelihood to learn something from these tasks is too low. So, tasks that are perceived as either not risky at all or too risky do not have the potential to satisfy $n$ Achievement motivated persons. For them, tasks and behaviors with moderate perceived risk levels are most attractive (and challenging) as they maximize the chance to satisfy their needs (i.e. improving performance, better performance) (Pang, 2010).

This reasoning also implies that $n$ Achievement motivated people are not attracted to tasks that are not challenging at all because the likelihood that they will learn something from such tasks is too limited, or because they are not convinced that the execution of these tasks will improve their performance level. A similar pattern can be observed in firms that consider international expansion (Burpitt \& Rondinelli, 2000). That is, SMEs tend to enhance their international activities only when the decision-makers believe that internationalization will yield valuable results, not only in monetary value, but also in the acquisition of new skills, technologies, and organizational capabilities.

Tying these insights together, we expect an inverted U-shaped relation between $n$ Achievement, the risk perception of internationalization, and SME internationalization. With this, we follow Freel (2005) who shows that a certain level of risk (i.e., neither too high, nor 
too low) is needed to optimize SME performance. Accordingly, Dai et al. (2014) demonstrate an inverted U-shaped relationship between risk-taking behavior and the international scope of a firm, arguing that a moderate international scope is optimal for an SME. Tying our arguments together that highly $n$ Achievement motivated entrepreneurs prefer moderate risks, and that they are more likely to portray higher levels of internationalization (see Hypothesis 1), we propose that specifically for highly $n$ Achievement motivated entrepreneurs, the level of SME internationalization is at the highest level if their risk perception of internationalization is moderate rather than high or low. Hence,

H2: The risk perception of internationalization moderates the relation between the entrepreneur's n Achievement and firm internationalization. That is, specifically for highly $n$ Achievement motivated entrepreneurs, the internationalization is at the highest level when the risk of internationalization is perceived as moderate.

\section{Data Collection, Measures, and Methods}

\subsection{Participants and Data collection}

In Indonesia, there are several definitions of an SME. According to Law $n^{\circ}$ 20/2008 about Micro, Small, and Medium-sized Enterprises, a small enterprise is defined as a company with annual sales between 300 and 2.500 million Rupiah. (i.e., between 20 and 160 thousand Euro), and annual net worth between 50 and 500 million Rupiah. (i.e., between 3.2 and 32 thousand Euro). A medium-sized enterprise is a company with annual sales between 2.5 and 50 billion Rupiah. (i.e., between 160 and 3.200 thousand Euro) and annual net worth between 0.5 and 10 billion Rupiah. (i.e., between 32 and 645 thousand Euro). The Bureau of Statistic in Indonesia (BPS) defines SMEs based on the number of employees; 5-19 employees is a small enterprise, and 20-99 employees a medium-sized enterprise. Finally, the Central Bank of The 
Republic of Indonesia defines small and medium-sized enterprises as companies with a maximum asset of 600 million Rupiah, excluding land and building (i.e., 38 thousand Euro), and annual sales less than 1 billion Rupiah. (i.e., 65 thousand Euro). We tied all these prerequisites together, and only selected companies answering to the most 'strict' SME conditions, in the case that two different anchor points exist (e.g., annual sales). The reason is simple: given that we examine personality characteristics, it is important not to include large firms (see above). Thus, the stricter the definition of an SME, the better.

We recruited SMEs listed in the database of the Indonesian East Java Bureau of SME Affairs in 2017. We selected the province of East Java because of its relatively high economic growth (5.45 percent), compared to the national average (5.07 percent) in 2017 (BPS, 2018a, 2018b). In addition, East Java Province has relatively high export values. For instance, its Export value of non-oil and gas commodities is the highest amongst other provinces, contributing to ten percent of Indonesia's economy (Kemendag, 2018).

The database consists of 627 SMEs that received incentives or participated in workshops or network events organized by the government in order to stimulate firm internationalization. Data collection consisted of three stages; first, we contacted all 627 SMEs to make sure that they were eligible and willing to participate in our study. Second, we scheduled an on-site visit to collect the data. Third, ten well-trained surveyors visited the SMEs for interviewing and data collection. To avoid miscommunication, the surveyors contacted the SMEs one week prior to the on-site visits.

We hired ten surveyors who work part-time at The Centre for Economics Policy Research (PPKE) of Faculty of Economics and Business Universitas Brawijaya. The data collection took place between April and September 2018. On average, one on-site visit took between 60-75 minutes, including the introduction, the interview, and breaks for minimizing fatigue (Olson, 2016; Rubin \& Rubin, 2011). We opted for on-site data collection because this 
ensured that the right person participated in the study and that the participants correctly interpreted the questions. Moreover, face-to-face data collection provides participants with the possibility to ask for clarification of the questions, which reduces ambiguity (Malhotra, Nunan, \& Birks, 2017).

For the first phase of the data collection, we contacted 485 SMEs by phone and 142 SMEs by mail. We only mailed companies when their phone number was not mentioned on the contact list. We received 113 positive responses out of the 485 calls. From the 142 mails, 18 mails returned due to invalid or changed addresses, and 13 SMEs responded positively. This resulted in an overall response rate of 20.1 percent. This response rate is acceptable and in line with recent studies in emerging South-East Asian economies where participation in on-site data collection is relatively low and where a survey and research tradition is not-so-well established (Isobe, Makino, \& Montgomery, 2000; Pangarkar, 2008; Pangarkar \& Klein, 2004). Reasons for not participating were unmotivated rejections to participate (184 SMEs), the enterprises did not longer exist (78 SMEs), and no answer or reply after several trials (239 SMEs).

While the surveyors were on their trip to visit the participating companies, they were instructed to search for eligible companies that were not listed in the database of the East Java Bureau of SME Affairs. As such, we introduced snowball sampling, allowing us to increase the representativeness of our sample. In Indonesia, many SMEs are not listed because they do not formally register themselves and many of them do not attend government events (Mourougane, 2012). This snowball sampling strategy resulted in an additional 52 companies yielding a total sample of 178 SMEs. Out of these 178 positive responses, two participants requested to withdraw their data, resulted in a final sample of 176 cases.

To minimize respondent bias, we asked participants to only refer to their international activities in 2017, instructed them that there are no "right" or "wrong" answers, and assured them that personal identity would be protected and used for academic's purposes only 
(Francioni, Musso, \& Cioppi, 2015). To confirm that there are minimal differences between the sample that originates from database of the East Java Bureau of SME Affairs and the sample obtained through snowball sampling, we executed independent sample t-tests on their $n$ Achievement $(\mathrm{t}=-.322$, df $174, \operatorname{sig} .748)$, level of internationalization $(\mathrm{t}=-1.968$, df 174 , sig $.051)$, number of employee ( $\mathrm{t}=-3.034$, df 174, sig .003), profit $(\mathrm{t}=.446$, df 161 , sig .656), age of the entrepreneur $\left(\mathrm{t}=.646\right.$, df 174 , sig .519), and gender $\left(\mathrm{Chi}^{2}=0.040\right.$, sig .862). The results portray that the bias that may arise from the two groups we investigated is at a minimum level.

We also took procedural precautions to prevent common method bias. Even though we only use one source of information; the entrepreneurs, we used different formats to assess each variable; an open-ended question for the assessment of implicit $n$ Achievement (the Operant Motive Test, see further), a five-point Likert scale to assess the risk perception of internationalization, and an open question for internationalization. Using different measurement formats reduces the likelihood of common method bias (Chang, van Witteloostuijn, \& Eden, 2010). Moreover, we also instructed participants to take a short break during the survey to avoid fatigue. This also increased the temporal separation of items, reducing a participant's tendency to use the previous answer for the next section (Podsakoff, MacKenzie, \& Podsakoff, 2012)

\subsection{Measures}

\subsubsection{Internationalization}

Compared to other types of internationalization, such as equity entry modes (e.g., joint ventures and greenfield investments), export turns out to be the most attractive entry-mode for SMEs in developing countries because export is flexible, requires limited financial and human resources, and imposes relatively low risks to SMEs (Burgel \& Murray, 2000; Pinho \& Martins, 2010; Young, Hamill, Wheeler, \& Davies, 1989). We use the firm's foreign sales as a percentage of total sales (FSTS) (Cadogan, Diamantopoulos, \& Siguaw, 2002; Reuber \& 
Fischer, 1997; Ruzzier, Antoncic, \& Hisrich, 2007; Ruzzier et al., 2006; Ruzzier \& Ruzzier, 2015) to assess the firm's position in the internationalization. This approach is in line with Cadogan et al. (2002), Pangarkar (2008), Hsu, Chen, and Cheng (2013) and Prange and Bruyaka (2016). Because the government does not record the export performance of SMEs, FSTS is selfreported by the participants.

\subsubsection{Risk Perception of Internationalization}

Since our study aimed to explore individual difference variables, we used the risk perceptions of internationalization and not an objective measure. To assess the participant's internationalization risk perception, we adopted Gripsrud's (1990) scale. This scale was developed to measure the attitude of entrepreneurs toward the barriers of export activity, which strongly fits with the foreign sales activity outcome measure used in this study. The scale consists of ten items such as "A major obstacle to internationalize is the strong competition on foreign markets", "Transportation cost is a major obstacle to internationalize", and "The uncertainty about the international political environment is a major obstacle". We adopted a 5points Likert-scale $(1=$ strongly disagree; $5=$ strongly agree $)$. The scale's internal consistency is satisfactory $(\alpha=0.77)$.

\subsubsection{Implicit Need for Achievement}

We used the Operant Motive Test (OMT: Kuhl and Scheffer (1999) and Kuhl, Scheffer, and Eichstaedt (2003) to assess the entrepreneur's implicit need for achievement. To complete the OMT, participants received 15 schematic drawings (see Figure 1 for an example), one at a time, and were asked to write down in a short form (i.e. short sentence, keywords) their spontaneous associations to the following four questions; (1) What is important for the person 
in this situation and what is the person doing?, (2) How does the person feel?, (3) Why does the person feel this way?, and (4) How does the story end?.

The OMT drawings are selected and validated in such a way that the responses are indicative of the participant's inner, underlying motives. For example, if the drawing depicts a man climbing a mountain, the participant can either think that "reaching the top, not quitting" is important for the man in the drawing, or that "climbing the mountain faster than anyone else" is the main driver of that man. In the first case, the answer represents the need for achievement whereas in the latter case, the story instead represents another motive: The power motive (Kuhl \& Scheffer, 1999)

Figure 1.

Example Drawing of OMT

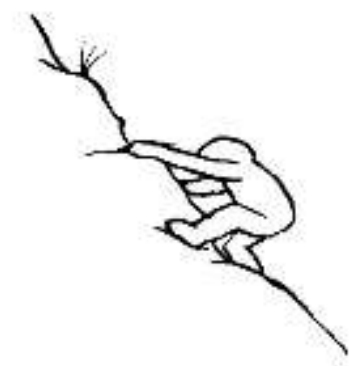

Source: (Kuhl \& Scheffer, 1999; Kuhl et al., 2003)

Three well-trained coders from Entrepreneurship Laboratory (Lab KWU) of Faculty of Economics and Business Universitas Brawijaya independently coded the responses using the OMT coding manual from Kuhl and Scheffer (1999). The manual provides strict guidelines on how answers need to be scored. That is, for $n$ Achievement, each picture was scored 1 (one) if 
the response contained strong references to any of the five themes that are indicative of the achievement motive and scored 0 (zero) if no reference to achievement was present. The five themes are 'Experiencing flow while executing challenging task', 'Presence of an internal standard of excellence', 'Coping with failure', 'Pressure to reach a goal', and 'Fear of failure'. The inter-rater reliability amongst three coders was high $(\alpha=0.97)$. Extensive research on the OMT shows that OMT is a reliable and valid measurement for the implicit need for achievement (Baumann, Kaschel, \& Kuhl, 2005; Baumann, Kazen, \& Kuhl, 2010; Kazen \& Kuhl, 2011; Kuhl et al., 2003; Scheffer, Kuhl, \& Eichstaedt, 2003).

\subsubsection{Control Variables}

In order to have a deeper understanding of the relationship between implicit need for achievement, risk perception, and internationalization, we included several control variables suggested by prior studies. We included gender ( $0=$ Male, $1=$ Female $)$ because Saeed, Yousaf, and Alharbi (2017) argued that female directors have a positive impact on the internationalization of the firm and Falkner and Hiebl (2015) found that male entrepreneurs show a greater interest toward risks. Age of participants, age of firms, size of firms, educational level and sector of industry (Acedo \& Florin, 2006; Cavusgil \& Naor, 1987; Coviello \& Jones, 2004; Hsu et al., 2013; Wiklund \& Shepherd, 2003) were included because these variables represent the experience of participants in taking up challenging business decision. The sector of the industry was included because each industry may have a different internationalization pattern. Because the majority of the SMEs in East Java is active in the art and handicraft sector, the sector of industry variable was treated as a dummy variable $(1=$ 'art and handicraft'; $0=$ 'other'). 


\subsection{Method}

Our dependent variable (FSTS) is denoted as a percentage of the sales that is exported to foreign countries. A considerable number of companies did not export anything of their production to foreign countries $(n=98)$ and twenty companies exported their whole production $(n=20)$. The export percentage of the other companies $(n=58)$ was roughly continuously distributed between these boundaries (that is, $0-100 \%$ ). Because the dependent variable is piled up at zero and one and because the estimated values should be bounded between zero and one, ordinary least square regressions are not well suited to test our hypotheses (Wooldridge, 2005). Given the specific distribution of our dependent variable, we applied the left and right-censored Tobit regression model. Tobit models are commonly used to study censored data and are more powerful than many other regression models in these cases (Saeed et al., 2017; Zhou, 2019). We performed a hierarchical Tobit procedure with robust standard errors involving a curvilinear effect of risk perception on the relationship between $n$ Achievement and FSTS (Dawson, 2014) The following regression equation was used to test the curvilinear effect of risk perception $(Z)$ for $n$ Achievement motivated entrepreneurs (X) on FSTS (Y):

Equation 1: $Y^{*}=\beta_{0}+\beta_{1} X+\beta_{2} Z+\beta_{3} Z^{2}+\beta_{4} X Z+\beta_{5} X Z^{2}+C_{0}$

To facilitate the interpretation of the parameter estimates, we mean-centered each predictor variable and this prior to the creation of the interaction and squared terms (Darlington \& Hayes, 2016; Hayes, 2017). Gender, age of participants, age of firm, size of firm, educational level and sector of industry were entered as control variables ( $\mathrm{C}$ in Equation 1). The independent variables were entered into the regression model in four successive steps. We first entered the control variables into the model (Model 0), followed by $n$ Achievement and risk perception (Model 1), the linear interaction between risk perception and $n$ Achievement (Model 2), and 
finally, risk perception squared and the interaction between $n$ Achievement and risk perception squared (Model 3). Value inflation factors (VIF) were all far below the recommended cut-off point of 5 (Hair, 2010; Hair, Black, Babin, Anderson, \& Tatham, 2006), indicating that multicollinearity is not an issue.

\section{Results}

Table 1 presents the demographic characteristics of our participants. In our study, the art and handicraft sector dominates the population. This is consistent with the export data we obtained from the East Java Bureau of SME Affairs. Most of our participants had a middle to low educational background.

Table 1

Demographic Characteristics

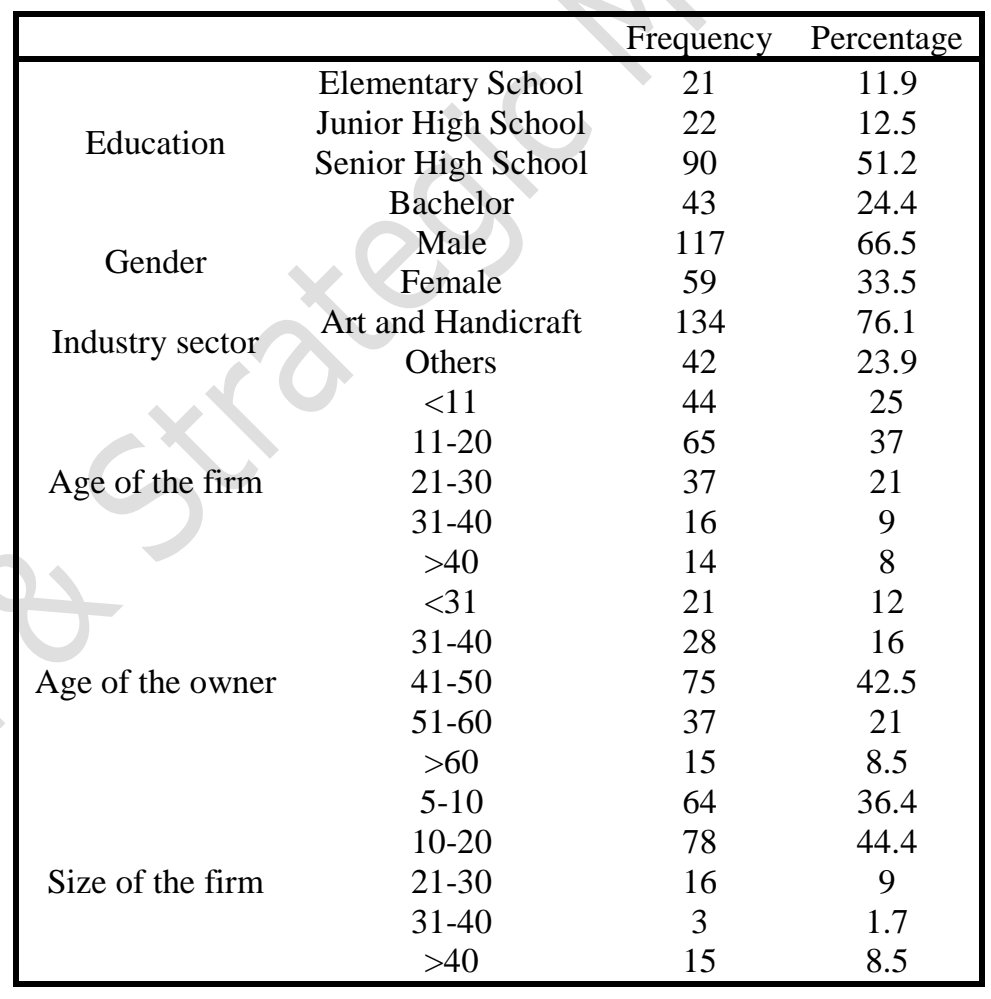

Table 2 shows the Pearson correlation between all variables. The positive and significant correlation between $n$ Achievement and internationalization (FSTS) is consistent with the idea that $n$ Achievement is positively associated with challenging tasks and entrepreneurial action 
(McClelland, 1965a, 1965b, 1985; McClelland et al., 1953; Pang, 2010; Sagie \& Elizur, 1999; Schultheiss \& Brunstein, 2010). Furthermore, the risk perception of internationalization is not significantly correlated with FSTS.

Table 2

Descriptive and Correlation of Variables

\begin{tabular}{|lccccccc|}
\hline & Mean & SD & 1 & 2 & 3 & 4 & 5 \\
\hline $\begin{array}{l}\text { Age of the } \\
\text { firm }\end{array}$ & 20.61 & 14.8 & 1 & & & & \\
$\begin{array}{l}\text { Age of the } \\
\text { owner }\end{array}$ & 46.38 & 11.1 & $.441^{* *}$ & 1 & & & \\
$\begin{array}{l}\text { Size of the } \\
\text { firm }\end{array}$ & 16.94 & 18.19 & -.013 & -.075 & 1 & & \\
$\begin{array}{l}\text { FSTS } \\
n \text { Achievement }\end{array}$ & 22.10 & 34.33 & -.035 & $-.183^{*}$ & $.297^{* *}$ & 1 & \\
Risk & 5.06 & 1.922 & .124 & -.082 & -.000 & $.190^{*}$ & 1 \\
Perception & 3.368 & .638 & -.076 & -.029 & -.064 & .059 & .023 \\
\hline
\end{tabular}

Notes: FSTS (Foreign Sales as a percentage of Total Sales), $n$ Achievement (Implicit Needs for Achievement).

Table 3 presents the results of the analysis involving the curvilinear interaction effects of risk perception on the relationship between $n$ Achievement and FSTS. To control for possible confounding factors, we first regressed FSTS on all control variables. Model 0 shows that the age of the entrepreneur and firm size reached significance (see Table 3). We then entered the linear effects of $n$ Achievement and risk perception in Model 1. Consistent with our previous discussion and the found correlations, Model 1 shows a significant, linear, and positive effect of $n$ Achievement on FSTS. $n$ Achievement, risk perception, and its linear interaction with risk perception were entered in Model 2. The positive and significant interaction term indicates that $n$ Achievement and risk perception do interact in the entrepreneur's decision to internationalize. Finally, and most importantly, the curvilinear effect of risk perception on the relationship between $n$ Achievement and FSTS were entered. Both the quadratic term of risk perception and 
its interaction term with $n$ Achievement are significant. However, and contrary to our expectations, both terms are positive.

Table 3.

Hierarchical Tobit Regressions of Risk Perception Moderation on $n$ Achievement and FSTS

\begin{tabular}{|c|c|c|c|c|c|c|c|c|c|c|c|c|}
\hline & & $\begin{array}{c}\text { Model } \\
0\end{array}$ & & & $\begin{array}{c}\text { Model } \\
1\end{array}$ & & & $\begin{array}{c}\text { Model } \\
2\end{array}$ & & & $\begin{array}{c}\text { Model } \\
3\end{array}$ & + \\
\hline & $\mathrm{B}$ & SE & Sig & $\mathrm{B}$ & SE & Sig & B & SE & Sig & $\mathrm{B}$ & SE & Sig \\
\hline Constant & 23.87 & 45.886 & .609 & 18.325 & 44.815 & .689 & 29.165 & 44.660 & .507 & 6.460 & 44.020 & .878 \\
\hline Education & 7.726 & 14.428 & .647 & 12.056 & 14.501 & .470 & 7.006 & 14.469 & .661 & 1.566 & 14.328 & .918 \\
\hline Gender & 2.012 & 14.75 & .896 & -.284 & 14.601 & .985 & 2.635 & 14.190 & .857 & 6.395 & 13.869 & .646 \\
\hline Sector Industry & 5.037 & 15.23 & .769 & -1.822 & 15.319 & .914 & -6.252 & 15.180 & .702 & -4.198 & 14.831 & .788 \\
\hline Age of Firm & .247 & .557 & .641 & .009 & .529 & .986 & .089 & .490 & .862 & .074 & .452 & .879 \\
\hline Age of Owner & $\begin{array}{c}- \\
1.480\end{array}$ & .682 & .045 & -1.255 & .652 & .084 & -1.440 & .661 & .040 & -1.132 & .633 & .048 \\
\hline Size of Firm & 1.150 & .443 & .001 & 1.152 & .452 & .001 & 1.155 & .420 & .000 & .946 & .375 & .004 \\
\hline \multicolumn{13}{|l|}{ Main Variables } \\
\hline$n$ Achievement & & & & 9.100 & 4.07 & .014 & 8.238 & 3.866 & .023 & 2.754 & 4.504 & .553 \\
\hline $\mathrm{RP}$ & & & & .200 & 10.316 & .984 & 1.805 & 10.653 & .858 & 7.602 & 9.771 & .432 \\
\hline$n$ Achievement*RP & & & & & & & 15.409 & 5.932 & .003 & 16.827 & 5.014 & .001 \\
\hline $\mathrm{RP}^{2}$ & & & & & & & & & & 49.320 & 12.621 & .000 \\
\hline $\begin{array}{c}n \text { Achievement } \\
* \mathrm{RP}^{2}\end{array}$ & & & & & & & & & & 12.159 & 5.99 & .086 \\
\hline \multicolumn{13}{|l|}{ Model Fit } \\
\hline Wald statistic & \multicolumn{2}{|c|}{16.53 on $6 \mathrm{df}$} & .017 & \multicolumn{2}{|c|}{21.58 on $8 \mathrm{df}$} & .005 & \multicolumn{2}{|c|}{28.76 on $9 \mathrm{df}$} & .000 & \multicolumn{2}{|c|}{39.83 on $11 \mathrm{df}$} & .000 \\
\hline Log-likehood & \multicolumn{3}{|c|}{-417.1 on $8 \mathrm{df}$} & \multicolumn{3}{|c|}{-414 on $10 \mathrm{df}$} & \multicolumn{3}{|c|}{-409.4 on $11 \mathrm{df}$} & \multicolumn{3}{|c|}{-401.8 on $13 \mathrm{df}$} \\
\hline $\mathrm{P}(>\mathrm{Chi})$ & \multicolumn{3}{|c|}{ n.a } & \multicolumn{3}{|c|}{.045} & \multicolumn{3}{|c|}{.002} & \multicolumn{3}{|c|}{.000} \\
\hline
\end{tabular}

Notes: FSTS (Foreign Sales as a percentage of Total Sales), $n$ Achievement (Implicit Needs for Achievement)

RP (Risk Perception of Internationalization).

To facilitate the interpretation of the complex interaction effect between risk perception and $n$ Achievement on the FSTS, we plotted the curvilinear interaction for entrepreneurs who scored low (mean - $1 \mathrm{SD}$ ), moderate (mean), and high (mean + $1 \mathrm{SD}$ ) on $n$ Achievement. As 
shown in Figure 2, different quadratic relations between risk perception and FSTS emerge for different levels of $n$ Achievement. Contrary to our expectations, the FSTS seems to be the lowest when internationalization is associated with moderate risk levels and this especially for entrepreneurs who score high on $n$ Achievement. To affirm whether our visual inspection is valid, we tested the curvilinear effects for different levels of $n$ Achievement according to the procedure outlined by Dawson (2014). We estimated the curvilinear effects for three plotted levels of $n$ Achievement. These results show that when $n$ Achievement is low (mean $-1 \mathrm{SD}$ ), the curvature of risk perception does not differ significantly from 0 (low: $t=1.56, p>.05$ ) whereas the curvatures are significant and positive when $n$ Achievement is medium (mean) or high (mean +1 SD) (medium: $\mathrm{t}=3.91, \mathrm{p}<.01$; high: $\mathrm{t}=3.59, \mathrm{p}<.01)$.

Figure 2.

FSTS as a function of $n$ Achievement and Risk Perception

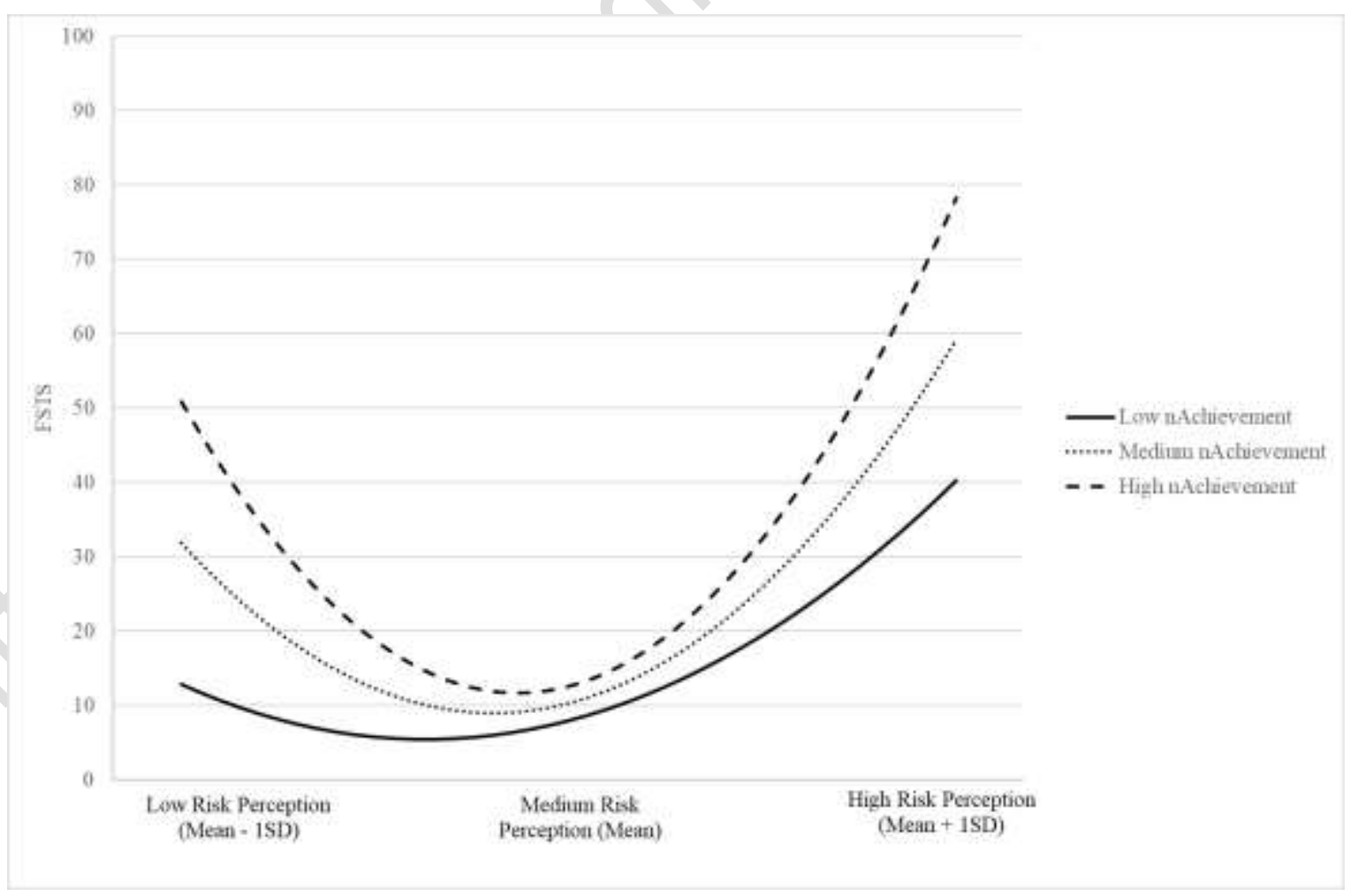




\section{Discussion}

The results of our study clearly indicate that the level of the entrepreneur's $n$ Achievement in combination with her/his perception of the internationalization risk impacts the company's degree of internationalization. In line with McClelland (1965), Pang (2010), and Slabbinck et al. (2018), our result shows that implicit need for achievement is positively associated with a challenging task, such as internationalization; H1. Interestingly, our expectation (H2) about the inverted U-shaped moderating effect of risk perception of internationalization on the relationship between $n$ Achievement and internationalization for highly $n$ Achievement motivated entrepreneurs is not supported by our results. The results indicate that the highest level of internationalization is most likely achieved by a highly $n$ Achievement motivated entrepreneur whose risk perception of internationalization is very high whereas the lowest level of internationalization is observed for entrepreneurs whose risk perception of internationalization is moderate. Notably, the high level of internationalization for $n$ Achievement motivated entrepreneurs whose internationalization risk perception is high is somewhat opposed to Dai et al. (2014) and Freel (2005), who contend that the highest degree of internationalization is associated with a moderate level of risk.

Two alternative explanations may account for this unexpected result. First, the vast majority of SMEs in Indonesia sell their products for the international market through intermediaries such as traders, exporting companies, or trade houses (Tambunan, 2007). As a result, these SMEs do not have direct contact with foreign companies and markets. Hence, they may perceive their type of export, which is indirect export, as an activity with low risk. This may explain why, in our sample, $n$ Achievement motivated entrepreneurs keep selling a lot of their products to the international market even though, in general, internationalization is perceived as a high-risk activity. 
For the second alternative explanation, we rely on Atkinson and Litwin's (1960) theory, which distinct $n$ Achievement into Hope of Success (HS) and Fear of Failure (FF). HS and FF explain how $n$ Achievement motivated individuals respond to risks (Pang, 2010). Atkinson and Litwin (1960) and Brody (1963) posit that an HS motivated entrepreneur tends to choose a task with a moderate level of risk and avoids a task with a too low and too high level of risk. This idea is in line with our $n$ Achievement inverted U-shaped model. However, FF motivated individuals act oppositely to risks. Individuals motivated by FF do not mind to fail in a highrisk environment because they can blame the failure to external causes (Brockhaus, 1980). Specifically, FF motivated individuals are likely to avoid feelings of anxiety (Atkinson, 1957; Atkinson \& Litwin, 1960; Clark et al., 1956; de Charms \& Dave, 1965). This fear for anxiety may push people to tasks with either low or high level of risk, preventing them from engaging in tasks with a moderate level of risk. Logically, for low-risk tasks, odds for failure are low, so anxiety is not necessary. To the contrary, the odds for failure are the highest for high-risk tasks. Yet, no one will blame failure in these cases, so here as well, anxiety is not necessary as well.

For tasks with a moderate level of risk, feelings of anxiety are at the highest level. That is, a moderate risk task is doable, but failure is likely. This outcome uncertainty may prevent FF motivated people to engage in tasks with moderated perceived risk levels (Atkinson, 1957). Related to our study, it could be that our participants were mainly motivated by fear of failure. They sell internationally through indirect export because it is the best option to sustain their business. However, should their international business activity collapse, they may attribute this to the intermediate export company.

Given that our study is one of the first that has been conducted in South-East Asia, our results suggest that the findings of studies conducted in Western countries may also be valid for SMEs in developing countries in general and South-East Asian countries in particular. Moreover, our study also contributes to the International Entrepreneurship field by showing 
that the implicit needs or motives of an entrepreneur ( $n$ Achievement) partially determine the internationalization process of their SMEs. Hence, we provide evidence that besides firm and environmental characteristics, also personality - and more specifically implicit motives - play a role in SME internationalization.

Our findings have several important implications. First, we show that the personality of the entrepreneur can best be considered in governmental and educational efforts to increase the level of internationalization of the firm. As an individual's level of $n$ Achievement is already formed early in life (McClelland \& Pilon, 1983) and the level of education also affects the personality and behavior of the entrepreneur, governments may formulate an Achievementoriented educational program that already starts at a very early age. Second, because our results yield different international behaviors for different types of entrepreneurs (e.g. high $n$ Achievement entrepreneurs who perceive internationalization as either a risky or non-risky business activity) policy-makers could formulate tailor-made policies adapted to these different types.

Of course, every study has limitations. First, our sample is relatively small and limited to one country. More research on other and larger samples is needed to generalize our findings to other cultures. Moreover, because high-quality databases that include all SMEs in a specific region and/or monitor the performance and activities of these SMEs do not exist in most developing countries, we relied on self-reported measures of one specific index of internationalization, FSTS. Of course, future research may incorporate other indices of internationalization and, if available, rely on other objective data sources to assess the SME's degree of internationalization. We generated our sample from two different sources due to a limitation of the government database. We also recruited a sample from non-listed SMEs to increase the sample representativeness and undertook several steps to ensure that our sample is free from sample selection bias: we have no significant difference between two sample sources 
in terms of independent and dependent variables used in our study and did not find any proof for sample differences in relation to our outcomes variable (Cuddeback, Wilson, Orme, \& Combs-Orme, 2004; Deschacht \& Goeman, 2015). Future research in developing countries with less-established database should be aware of this issue.

In a similar vein, we focused on $n$ Achievement. We selected $n$ Achievement because of its relevance for entrepreneurial research (Ahmed, 1985; McClelland, 1965a, 1965b; Palmer, 1971; Pang, 2010; Robinson et al., 1991; Sagie \& Elizur, 1999). However, people are driven by three basic needs: The need for power, the need for affiliation, and the need for achievement (Schultheiss \& Brunstein, 2010). Future researchers might examine the impact of the other two needs as well; the need for power and the need for affiliation. People driven by the need for power derives satisfaction from the ability to influence, control, or impress others (Fodor, 2010). Individuals with a high need for power are associated with effective leadership (McClelland \& Burnham, 2008) and the behavior of ingratiating opposing opinions (Fodor, 2010), altruistic behavior (Hermans et al., 2017), and creativity (Fodor \& Greenier, 1995). The need for affiliation is a motivation which energizes people to seek closeness, love, and to avoid conflicts with others (McClelland, 1985). Individuals with high $n$ Affiliation have large social networks and commonly are good at creating, maintaining, and restoring social interaction (Koestner \& McClelland, 1992). It is likely that different implicit motives may be linked to different types of internationalization. Besides exploring these other two basic needs as well, future research could also benefit from studying the different need for achievement categories; Hope of Success and Fear of Failure.

In addition, our study only focused on the (subjective) perception that an individual is associated with internationalization. Of course, exporting to or investing in some countries is (objectively) riskier than exporting to or investing in other countries. Hence, it would be worthwhile to include as well the objective risk levels of the destination countries in future 
studies. More research on the interplay between the explicit and implicit motives of the entrepreneurs, their (subjective) assessment of risk that they associate with (different forms of) internationalization and the objective assessment of the (objective) risk profiles of the countries they export to, ideally in a cross-cultural perspective, would give valuable additional insights into the internationalization process of SMEs.

Finally, our study is cross-sectional in nature. Longitudinal research on the relationship between the psychological profile of entrepreneurs and the internationalization process of SMEs would be worthwhile to investigate as well. Our results show that the psychological characteristics of entrepreneurs are relevant for many studies on the internationalization process of SME and call for future researchers to explore this relationship further. In addition, we also encourage researchers to explore the role of psychological processes in a larger scope, for example, by investigating the differential impact of the personality of individuals in SMEs versus large companies.

\section{Acknowledgement}

We appreciate the constructive insights and suggestions from two anonymous reviewers. We thank to Petra Andries and Rudy Martens for the support and guidance. We also thank PPKE and Lab KWU Faculty of Economics and Business Universitas Brawijaya for the endless support during data collection. This research was fully funded by Indonesia Endowment Fund for Education (LPDP) (Contract PRJ-1748/LPDP.3/2016) and Universitas Brawijaya.

\section{References}

Acedo, F. J., \& Florin, J. (2006). An entrepreneurial cognition perspective on the internationalization of SMEs. Journal of International Entrepreneurship, 4(1), 49-67. doi:10.1007/s10843-006-04829

Acedo, F. J., \& Jones, M. V. (2007). Speed of internationalization and entrepreneurial cognition: Insights and a comparison between international new ventures, exporters and domestic firms. Journal of World Business, 42(3), 236-252. doi:10.1016/j.jwb.2007.04.012 
Acs, Z., Dana, L., \& Jones, M. (2003). Toward new horizons: the internationalization of entrepreneurship. Journal of International Entrepreneurship, 1(1), 5-12.

Ahmed, S. U. (1985). nAch, risk-taking propensity, locus of control and entrepreneurship. Personality and Individual Differences, 6(6), 781-782.

Al-Hyari, K., Al-Weshah, G., \& Alnsour, M. (2012). Barriers to internationalization in SMEs: evidence from Jordan. Marketing Intelligence \& Planning, 30(2), 188-211. doi:10.1108/02634501211211975

Amorós, J. E., Basco, R., \& Romaní, G. (2014). Determinants of early internationalization of new firms: the case of Chile. International Entrepreneurship and Management Journal, 12(1), 283-307. doi:10.1007/s11365-014-0343-2

Atkinson, J. W. (1957). Motivational determinants of risk-taking behavior. Psychological Review, 64, 359-372.

Atkinson, J. W., \& Litwin, G. H. (1960). Achievement motive and test anxiety conceived as motive to approach success and motive to avoid failure. Journal of Abnormal and Social Psychology, $60(1)$.

Bappenas. (2016). Penguatan UMKM untuk pertumbuhan ekonomi yang berkualitas [Press release]. Retrieved

from https://www.bappenas.go.id/files/8014/8116/6753/Warta_KUMKM_2016_Vol_5_No_1.pdf

Baumann, N., Kaschel, R., \& Kuhl, J. (2005). Striving for Unwanted Goals Stress Dependent Discrepancies Between Explicit and Implicit Achievement Motives reduce Subjective WellBeing and Increase Psychosomatic Symptoms. Journal of Personality and Social Psychology, 89(5), 781-799.

Baumann, N., Kazen, M., \& Kuhl, J. (2010). Implicit motives: A look from personality system interaction theory. In O. C. Schultheiss \& J. C. Brunstein (Eds.), Implicit Motives (pp. 375-403). New York: Oxford University Press.

Bernecker, K., \& Job, V. (2010). Assessing implicit motives with an online version of the picture story exercise. Motivation and Emotion, 35(3), 251-266. doi:10.1007/s11031-010-9175-8

Bianchi, R., \& Noci, G. (1998). "Greening" SME's competitiveness. Small Business Economics, 11(3), 269-281.

Bing, M. N., Stewart, S. M., Davison, H. K., Green, P. D., McIntyre, M. D., \& James, L. R. (2007). An integrative typology of personality assessment for aggression: Implications for predicting counterproductive workplace behavior. Journal of Applied Psychology, 92(3), 722-744.

BPS. (2018a). Pertumbuhan Ekonomi Indonesia Triwulan IV 2017 [Press release]. Retrieved from https://www.bps.go.id/pressrelease/2018/02/05/1519/ekonomi-indonesia-triwulan-iv-2017-tumbuh-5-19-persen.html

BPS. (2018b). Pertumbuhan Ekonomi Jawa Timur 2018 [Press release]. Retrieved from https://jatim.bps.go.id/pressrelease/2019/02/06/1056/pertumbuhan-ekonomi-jawa-timurtahun-2018.html

Bradley, S. W., McMullen, J. S., Artz, K., \& Simiyu, E. M. (2012). Capital Is Not Enough: Innovation in Developing Economies. Journal of Management Studies, 49(4), 684-717. doi:10.1111/j.1467-6486.2012.01043.x

Brammer, S., Hoejmose, S., \& Marchant, K. (2011). Environmental Management in SMEs in the UK: Practices, Pressures and Perceived Benefits. Business Strategy and the Environment. doi:10.1002/bse.717

Brockhaus, R. H. (1980). Risk taking propensity of entrepreneurs. Academy of Management Journal, 23(3), 509.

Brody, N. (1963). N Achievement, test Anxiety, and Subjective Probability of Success in Risk Taking Behavior. Journal of Abnormal and Social Psychology, 66(5), 413-418.

Brouthers, K. D., Nakos, G., \& Dimitratos, P. (2015). SME Entrepreneurial orientation, international performance, and the moderating role of strategic alliances. Entrepreneurship Theory and Practice, 39(5), 1161-1187. doi:10.1111/etap.12101

Brunstein, J. C., \& Schmitt, C. H. (2004). Assessing individual differences in achievement motivation with the Implicit Association Test. Journal of Research in Personality, 38(6), 536-555. doi:10.1016/j.jrp.2004.01.003 
Bruton, G. D., \& Lau, C. M. (2008). Asian Management Research: Status Today and Future Outlook. Journal of Management Studies, 45(3), 636-659. doi:10.1111/j.1467-6486.2007.00758.x

Burgel, C., \& Murray, G. (2000). The international market entry choices of start-up companies in high technology industries. Journal of International Marketing, 8(2), 33-62.

Burpitt, W. J., \& Rondinelli, D. A. (2000). Small firms' motivations for exporting: To earn and learn? Journal of Small Business Management, 38(4).

Cadogan, J. W., Diamantopoulos, A., \& Siguaw, J. A. (2002). Export market-oriented activities: Their antecedents and performance consequences. Journal of International Business Studies, 33(3), 615.

Caiazza, R. (2016). Internationalization of SMEs in high potential markets. Trends in Food Science \& Technology, 58, 127-132. doi:10.1016/j.tifs.2016.10.002

Cavusgil, S. T., \& Naor, J. (1987). Firm and management characteristics as discriminators of export marketing activity. Journal of Business Research, 15(3), 221-235.

Cavusgil, S. T., \& Nevin, J. R. (1981). Internal determinants of export marketing behavior: An empirical investigation. Journal of Marketing Research, 18, 114.

Cerrato, D., Crosato, L., \& Depperu, D. (2016). Archetypes of SME internationalization: A configurational approach. International Business Review, 25(1), 286-295. doi:10.1016/j.ibusrev.2015.05.010

Chandler, G., \& Hanks, S. (1994). Founder competence, the environment, and venture performance. Entrepreneurship Theory and Practice, 18(3), 77-89.

Chang, S. J., van Witteloostuijn, A., \& Eden, L. (2010). From the editors: Common method variance in international business research. Journal of International Business Studies, 41(2), 178-184.

Che Senik, Z., Scott-Ladd, B., Entrekin, L., \& Adham, K. A. (2011). Networking and internationalization of SMEs in emerging economies. Journal of International Entrepreneurship, 9(4), 259-281. doi:10.1007/s10843-011-0078-x

Chen, J., Sousa, C. M. P., \& He, X. (2016). The determinants of export performance: a review of the literature 2006-2014. International Marketing Review, 33(5), 626-670. doi:10.1108/imr-102015-0212

Child, J., Hsieh, L., Elbanna, S., Karmowska, J., Marinova, S., Puthusserry, P., . . Z Zhang, Y. (2017). SME international business models: The role of context and experience. Journal of World Business, 52(5), 664-679. doi:10.1016/j.jwb.2017.05.004

Child, J., \& Hsieh, L. H. Y. (2014). Decision mode, information and network attachment in the internationalization of SMEs: A configurational and contingency analysis. Journal of World Business, 49(4), 598-610. doi:10.1016/j.jwb.2013.12.012

Chye Koh, H. (1996). Testing hypotheses of entrepreneurial characteristics. Journal of Managerial Psychology, 11(3), 12-25. doi:10.1108/02683949610113566

Clark, A. R., Teevan, R., \& Ricciuti, H. N. (1956). Hope of Success and Fear of Failure as Aspect of Need for Achievement. Journal of Abnormal and Social Psychology, 53(2), 182-186.

Collins, C. J., Hanges, P. J., \& Locke, E. A. (2004). The Relationship of Achievement Motivation to Entrepreneurial Behavior: A Meta-Analysis. Human Performance, 17, 95-117.

Collins, C. J., Locke, E., \& Hanges, P. (2000). The relationship of need for achievement to entrepreneurial behavior: A meta-analysis. Working paper. University of Maryland. College Park, MD.

Cooper. (1983). An achievement motivation nomological network. Journal of Personality and Social Psychology, 44(4), 841-861.

Coviello, N. E., \& Jones, M. V. (2004). Methodological issues in international entrepreneurship research. Journal of Business venturing, 19(4), 485-508. doi:10.1016/j.jbusvent.2003.06.001

Cuddeback, G., Wilson, E., Orme, J. G., \& Combs-Orme, T. (2004). Detecting and Statistically Correcting Sample Selection Bias. Journal of Social Service Research, 30(3), 19-33. doi:10.1300/J079v30n03_02

Da Rocha, A., Kury, B., \& Monteiro, J. (2009). The diffusion of exporting in Brazilian industrial clusters. Entrepreneurship \& Regional Development, 21(5), 529-552. doi:10.1080/08985620802373453 
Dai, L., Maksimov, V., Gilbert, B. A., \& Fernhaber, S. A. (2014). Entrepreneurial orientation and international scope: The differential roles of innovativeness, proactiveness, and risk-taking. Journal of Business venturing, 29(4), 511-524. doi:10.1016/j.jbusvent.2013.07.004

Darlington, R. B., \& Hayes, A. F. (2016). Regression Analysis and Linear Models: Concepts, Applications, and Implementation.

Dawson, J. F. (2014). Moderation in management research: What, why, when and how. Journal of Business and Psychology, 29, 1-19.

de Charms, R., \& Carpenter, V. (1968). Measuring motivation in culturally disadvantaged children Research and development toward the improvement of education. Madison: WI: Educational Research Services.

de Charms, R., \& Dave, P. N. (1965). Hope of success, fear of failure, subjective probability, and risktaking behavior. Journal of Personality and Social Psychology, 1(6), 558-568.

de Clercq, D., Sapienza, H. J., \& Crijns, H. (2005). The Internationalization of Small and Medium-Sized Firms. Small Business Economics, 24(4), 409-419. doi:10.1007/s11187-005-5333-x

Deschacht, N., \& Goeman, K. (2015). Selection Bias in Educational Issues and the Use of Heckman's Sample Selection Model. 35-52. doi:10.2307/j.ctt14jxsqg.5

Dimitratos, P., Buck, T., Fletcher, M., \& Li, N. (2016). The motivation of international entrepreneurship: The case of Chinese transnational entrepreneurs. International Business Review, 25(5), 11031113. doi:10.1016/j.ibusrev.2016.01.012

Dimitratos, P., Johnson, J. E., Plakoyiannaki, E., \& Young, S. (2016). SME internationalization: How does the opportunity-based international entrepreneurial culture matter? International Business Review, 25(6), 1211-1222. doi:10.1016/j.ibusrev.2016.03.006

Etemad, H. (2004). Internationalization of Small and Medium sized Enterprises A Grounded Theoretical Framework and an Overview. Canadian Journal of Administrative Sciences / Revue Canadienne des Sciences de l'Administration, 21(1), 1.

Falkner, E. M., \& Hiebl, M. R. W. (2015). Risk management in SMEs: a systematic review of available evidence. The Journal of Risk Finance, 16(2), 122-144. doi:10.1108/jrf-06-2014-0079

Feather, N. T. (1963). The relationship of Expectation of Success to Reported Probability, Task Structure, and Achievement Related Motivation. Journal of Abnormal and Social Psychology, 66(3), 231-238.

Figueira de Lemos, F., Johanson, J., \& Vahlne, J. E. (2011). Risk management in the internationalization process of the firm: A note on the Uppsala model. Journal of World Business, 46(2), 143-153. doi:10.1016/j.jwb.2010.05.008

Fodor, E. M. (2010). Power Motivation. In O. C. Schultheiss \& J. C. Brunstein (Eds.), Implicit Motives (pp. 3-29). New York: Oxford University.

Fodor, E. M., \& Greenier, K. D. (1995). The power motive, self-affect, and creativity. Journal of Research in Personality, 29, 242-252.

Francioni, B., Musso, F., \& Cioppi, M. (2015). Decision-maker characteristics and international decisions for SMEs. Management Decision, 53(10), 2226-2249. doi:10.1108/md-03-2015-0094

Freel, M. S. (2005). Perceived Environmental Uncertainty and Innovation in Small Firms. Small Business Economics, 25(1), 49-64. doi:10.1007/s11187-005-4257-9

Frese, M., \& Gielnik, M. M. (2014). The Psychology of Entrepreneurship. Annual Review of Organizational Psychology and Organizational Behavior, 1(1), 413-438. doi:10.1146/annurevorgpsych-031413-091326

George, G., Wiklund, J., \& Zahra, S. A. (2016). Ownership and the Internationalization of small firms. Journal of Management, 31(2), 210-233. doi:10.1177/0149206304271760

Gripsrud, G. (1990). The determinants of export decisions and attitudes to a distant market: Norwegian fishery exports to Japan. Journal of International Business Studies, 21(3), 469-485.

Hair, J. F. (2010). Multivariate Data Analysis. Cornell University: Prentice Hall.

Hair, J. F., Black, W. C., Babin, B. J., Anderson, R. E., \& Tatham, R. L. (2006). Multivariate Data Analysis: (6 ed.). New Jersey: Prentice Hall.

Hayes, A. F. (2017). Introduction to mediation, moderation, and conditional process analysis: A regression-based approach. New York: Guildford Publications.

Hermans, J., Slabbinck, H., Vanderstraeten, J., Brassey, J., Dejardin, M., Ramdani, D., \& van Witteloostuijn, A. (2017). The power paradox: Implicit and explicit power motives, and the 
importance attached to prosocial organizational goals in SMEs. Sustainability, 9(11), 2001. doi:10.3390/su9112001

Hitt, M. A., Hoskisson, R. E., \& Kim, H. (1997). International diversification: Effects on innovation and firm performance in product-diversified firms. Academy of Management Journal, 40(4).

Hsu, W.-T., Chen, H.-L., \& Cheng, C.-Y. (2013). Internationalization and firm performance of SMEs: The moderating effects of CEO attributes. Journal of World Business, 48(1), 1-12. doi:10.1016/j.jwb.2012.06.001

Indrawati, S. M. (2017). Prospek Perekonomian Indonesia 2017 [Press release]

Isobe, T., Makino, S., \& Montgomery, D. B. (2000). Resource commitment, entry timing and market performance of foreign direct investments in emerging economies: The case of Japanese international joint ventures in China. Academy of Management Journal, 43(3), 468-484.

Japhta, R. (2016). UKM yang dimiliki wanita di Indonesia: Kesempatan emas untuk institusi keuangan lokal [Press release]

Javalgi, R. G., \& Todd, P. R. (2011). Entrepreneurial orientation, management commitment, and human capital: The internationalization of SMEs in India. Journal of Business Research, 64(9), 10041010. doi:10.1016/j.jbusres.2010.11.024

Johanson, J., \& Vahlne, J. E. (1977). The Internationalization Process of the Firm A Model of Knowledge Development and Increasing Foreign Market Commitments. Journal of International Business Studies, 8(1), 23-32.

Johanson, J., \& Vahlne, J. E. (2009). The Uppsala internationalization process model revisited: From liability of foreignness to liability of outsidership. Journal of International Business Studies, 40(9), 1411-1431. doi:10.1057/jibs.2009.24

Johnson, B. R. (1990). Toward a multidimensional model of entrepreneurship: The case of achievement motivation and the entrepreneur. Entrepreneurship Theory \& Practice, 14(3), 39-54.

Jones, M. V., Coviello, N., \& Tang, Y. K. (2011). International Entrepreneurship research (1989-2009): A domain ontology and thematic analysis. Journal of Business venturing, 26(6), 632-659. doi:10.1016/j.jbusvent.2011.04.001

Jones, M. V., \& Covielo, N. E. (2005). Internationalisation Conceptualising an Entrepreneurial Process of Behaviour in Time. Journal of International Business Studies, 36(3), 284-303.

Kauppinen, A., \& Juho, A. (2012). Internationalisation of SMEs from the perspective of social learning theory. Journal of International Entrepreneurship, 10(3), 200-231. doi:10.1007/s10843-0120093-6

Kazen, M., \& Kuhl, J. (2011). Directional discrepancy between implicit and explicit power motives is related to well-being among managers. Motivation and Emotion, 35, 317-327. doi:10.1007/s11031-011-9219-8

Kemendag. (2018). Perkembangan Ekspor NonMigas (Provinsi) Periode : 2013-2018. Retrieved from http://www.kemendag.go.id/id/economic-profile/indonesia-export-import/growth-of-non-oiland-gas-export-provincial

Knight, G. A., \& Cavusgil, S. T. (2004). Innovation, Organizational Capabilities, and the Born-Global Firm. Journal of International Business Studies, 35(2), 124-141.

Knight, G. A., \& Liesch, P. W. (2016). Internationalization: From incremental to born global. Journal of World Business, 51(1), 93-102. doi:10.1016/j.jwb.2015.08.011

Koestner, R., \& McClelland, D. C. (1992). The affiliation motive. In C. P. Smith (Ed.), Motivation and personality: Handbook of thematic content analysis (pp. 205-210). NY: Cambridge University Press.

Kollner, M. G., \& Schultheiss, O. (2014). Meta-analytic evidence of low convergence between implicit and explicit measures of the needs for achievement, affiliation, and power. Frontier in Psychology, 5, 826. doi:10.3389/fpsyg.2014.00826

Kuhl, J., \& Scheffer, D. (1999). Der operante multi motive test (OMT): Manual [The operant multi motive test (OMT): Manual]. Germany: University of Osnabruck.

Kuhl, J., Scheffer, D., \& Eichstaedt, J. (2003). Der Operante Motiv Test (OMT): Ein neuer Ansatz zur Messung impliziter Motive [The operant motive test (OMT): A new approach to the assessment of implicit motives]. In F. Rheinberg \& J. Stiensmeier Pelster (Eds.), Diagnostik von Motivation und Selbstkonzept (pp. 129-149). Gottingen: Hogrefe. 
Lang, J. W., Zettler, I., Ewen, C., \& Hülsheger, U. R. (2012). Implicit motives, explicit traits, and task and contextual performance at work. Journal of Applied Psychology, 97(6), 1201-1217.

Leonidou, L. C. (2004). An Analysis of the Barriers Hindering Small Business Export Development. Journal of Small Business Management, 42(3), 279-302.

Li, Y., \& Peng, M. W. (2008). Developing theory from strategic management research in China. Asia Pacific Journal of Management, 25(3), 563-572. doi:10.1007/s10490-007-9083-y

Lin, C. (1998). Success factors of small and medium-sized enterprises in Taiwan: An analysis of cases. Journal of Small Business Management, 34(6), 43-56.

Ling, Y., Zhao, H., \& Baron, R. A. (2007). Influence of founder-CEOs' personal values on firm performance: Moderating effects of firm age and size. Journal of Management, 33(5), 673-696.

Litwin, G. H. (1966). Achievement motivation, expectancy of success, and risk-taking behavior. In J. W. Atkinson \& N. T. Feather (Eds.), A theory of achievement motivation. New York: Wiley.

Malhotra, N. K., Nunan, D., \& Birks, D. (2017). Marketing Research: An Applied Approach (5 ed.). London: Pearson.

McClelland, D. C. (1961). The achieving society. Princeton: NJ: van Nostrand.

McClelland, D. C. (1965a). N achievement and entrepreneurship: A longitudinal study. Journal of Personality and Social Psychology, 1(4).

McClelland, D. C. (1965b). Toward a theory of motive acquisition. The American Psychologist, 20(5), 321-333.

McClelland, D. C. (1985). How Motives, Skills, and Values Determine What People Do. American Psychologist, 40(7), 812-825.

McClelland, D. C., Atkinson, J. W., Clark, A. R., \& Lowell, E. L. (1953). The achievement motive. East Norwalk: CT: Appleton-Century-Croft.

McClelland, D. C., \& Burnham, D. H. (2008). Power is the great motivator: Harvard Business Review Press.

McClelland, D. C., Clark, A. R., Roby, T. B., \& Atkinson, J. W. (1949). The projective expression of needs. IV. The effect of the need for achievement on thematic apperception. Journal of Experimental Psychology, 39, 242-255.

McClelland, D. C., Koestner, R., \& Weinberger, J. (1989). How do self-attributed and implicit motives differ. Psychological Review, 96(4), 690-702.

McClelland, D. C., \& Pilon, D. A. (1983). Sources of adult motives in patterns of parent behavior in early childhood. Journal of Personality and Social Psychology, 44(3), 564-574.

McClelland, D. C., \& Watson, R. I. (1973). Power motivation and risk taking behavior. J Pers, 41(1), 121-139.

McDougall, P. P., \& Oviatt, B. M. (2000). International Entrepreneurship The Intersection of Two Research Paths. The Academy of Management Journal, 43(5), 902-906.

Meyer, K. E. (2007). Asian contexts and the search for general theory in management research: A rejoinder. Asia Pacific Journal of Management, 24(4), 527-534. doi:10.1007/s10490-007-90534

Meyer, K. E., \& Peng, M. W. (2016). Theoretical foundations of emerging economy business research. Journal of International Business Studies, 47(1), 3-22. doi:10.1057/jibs.2015.34

Miller, D., \& Toulouse, J. M. (1986). Chief executive personality and corporate strategy and structure in small firms. Management Science, 32, 1389-1409.

Mourougane, A. (2012). Promoting SME development in Indonesia (18151973). Retrieved from http://dx.doi.org/10.1787/5k918xk464f7-en

Muzychenko, O., \& Liesch, P. W. (2015). International opportunity identification in the internationalisation of the firm. Journal of World Business, 50(4), 704-717. doi:10.1016/j.jwb.2014.12.001

Nicholls, J. G. (1984). Achievement motivation: Conceptions of ability, subjective experience, task choice, and performance. Psychological Review, 91(3), 328-346. doi:10.1037/0033295X.91.3.328

Olson, K. (2016). Essential of qualitative interviewing. New York: Routledge.

Omri, W., \& Becuwe, A. (2014). Managerial characteristics and entrepreneurial internationalization: A study of Tunisian SMEs. Journal of International Entrepreneurship, 12(1), 8-42. doi:10.1007/s10843-013-0119-8 
Oparaocha, G. O. (2015). SMEs and international entrepreneurship: An institutional network perspective. International Business Review, 24(5), 861-873. doi:10.1016/j.ibusrev.2015.03.007

Oviatt, B. M., \& McDougall, P. P. (1994). Toward a Theory of International New Ventures. Journal of International Business Studies, 25(1), 45-64.

Oviatt, B. M., \& McDougall, P. P. (2005). Defining International Entrepreneurship and Modeling the Speed of Internationalization. Entrepreneurship Theory and Practice(September), 537.

Palmer, M. (1971). The Application of Psychological Testing to Entrepreneurial Potential. California Management Review, Spring(13), 32.

Pang, J. S. (2010). The Achievement Motive: A Review of Theory and Assessment of $n$ Achievement, Hope of Success, and Fear of Failure. In O. C. Schultheiss \& J. C. Brunstein (Eds.), Implicit Motives (pp. 30-70). New York: Oxford University Press.

Pang, J. S., Villacorta, M. A., Chin, Y. S., \& Morrison, F. J. (2009). Achievement motivation in the social context: Implicit and explicit Hope of Success and Fear of Failure predict memory for and liking of successful and unsuccessful peers. Journal of Research in Personality, 43(6), 1040-1052. doi:10.1016/j.jrp.2009.08.003

Pangarkar, N. (2008). Internationalization and performance of small- and medium-sized enterprises. Journal of World Business, 43(4), 475-485. doi:10.1016/j.jwb.2007.11.009

Pangarkar, N., \& Klein, S. (2004). The impact of control on joint venture performance: A contingency approach. Journal of International Marketing, 12(3), 86-107.

Peng, M. W., Bhagat, R. S., \& Chang, S.-J. (2010). Asia and global business. Journal of International Business Studies, 41(3), 373-376. doi:10.1057/jibs.2009.98

Perugini, M., Richetin, J., \& Zogmaister, C. (2010). Prediction of behavior. In B. Gawronski \& B. K. Payne (Eds.), Handbook of implicit social recognition: Measurement, theory, and applications (Vol. 10, pp. 255-278). New York: Guilford Press.

Pinho, J. C., \& Martins, L. (2010). Exporting barriers: Insights from Portuguese small- and mediumsized exporters and non-exporters. Journal of International Entrepreneurship, 8(3), 254-272. doi:10.1007/s10843-010-0046-x

Pinho, J. C., \& Prange, C. (2016). The effect of social networks and dynamic internationalization capabilities on international performance. Journal of World Business, 51(3), 391-403. doi:10.1016/j.jwb.2015.08.001

Podsakoff, P. M., MacKenzie, S. B., \& Podsakoff, N. P. (2012). Sources of method bias in social science research and recommendations on how to control it. Annu Rev Psychol, 63, 539-569. doi:10.1146/annurev-psych-120710-100452

Prange, C., \& Bruyaka, O. (2016). Better at home, abroad, or both? How Chinese firms use ambidextrous internationalization strategies to drive innovation. Cross Cultural \& Strategic Management, 23(2), 306-339. doi:10.1108/ccsm-07-2014-0079

Prange, C., \& Pinho, J. C. (2017). How personal and organizational drivers impact on SME international performance: The mediating role of organizational innovation. International Business Review, 26(6), 1114-1123. doi:10.1016/j.ibusrev.2017.04.004

Rauch, A., Frese, M., \& Utsch, A. (2005). Effects of human capital and long-term human resources development and utilization on employment growth of small-scale businesses: A causal analysis. Entrepreneurship Theory and Practice, November, 681-698.

Redmond, J., Walker, E., \& Wang, C. (2008). Issues for small businesses with waste management. Journal of Environment Management, 88(2), 275-285. doi:10.1016/j.jenvman.2007.02.006

Reuber, R., \& Fischer, E. (1997). The Influence of the Management Team's International Experience on the Internationalization Behaviors of SMEs. Journal of International Business Studies, 28(4), 807-825.

Rialp, A., Rialp, J., \& Knight, G. A. (2005). The phenomenon of early internationalizing firms: what do we know after a decade (1993-2003) of scientific inquiry? International Business Review, 14(2), 147-166. doi:10.1016/j.ibusrev.2004.04.006

Robinson, P. B., Huefner, J. C., \& Hunt, H. K. (1991). Entrepreneurial Research on Student Subjects Does Not Generalize to Real World Entrepreneurs. Journal of Small Business Management, $29(2), 42$.

Rubin, H. J., \& Rubin, I. S. (2011). Qualitative interviewing: The art of hearing data. Los Angeles: Sage. 
Ruzzier, M., Antoncic, B., \& Hisrich, R. D. (2007). The internationalization of SMEs: developing and testing a multi-dimensional measure on Slovenian firms. Entrepreneurship and Regional Development, 19(2), 161-183. doi:10.1080/08985620601137646

Ruzzier, M., Matlay, H., Hisrich, R. D., \& Antoncic, B. (2006). SME internationalization research: past, present, and future. Journal of Small Business and Enterprise Development, 13(4), 476-497. doi:10.1108/14626000610705705

Ruzzier, M., \& Ruzzier, M. K. (2015). On the relationship between firm size, resources, age at entry and internationalization: the case of Slovenian SMEs. Journal of Business Economics and Management, 16(1), 52-73. doi:10.3846/16111699.2012.745812

Ryan, J. C., Tipu, S. A., \& Zeffane, R. M. (2011). Need for achievement and entrepreneurial potential: a study of young adults in the UAE. Education, Business and Society: Contemporary Middle Eastern Issues, 4(3), 153-166.

Saeed, A., Yousaf, A., \& Alharbi, J. (2017). Family and state ownership, internationalization and corporate board-gender diversity. Cross Cultural \& Strategic Management, 24(2), 251-270. doi:10.1108/ccsm-11-2015-0159

Sagie, A., \& Elizur, D. (1999). Achievement motive and entrepreneurial orientation: A structural analysis. Journal of Organizational Behavior, 20, 375-387.

Scheffer, D., Kuhl, J., \& Eichstaedt, J. (2003). Der Operante Motiv-Test (OMT): Inhaltsklassen, Auswertung, Psychometrische Kennwerte und Validierung. (The Operant Motive test (OMT): Contents, Scoring, Psychometric Values, and Validation. In J. Stiensmeier Pelster \& F. Rheinberg (Eds.), Diagnostk van Motivation und Selbskonzept (Diagnostic of Motivation and Self-Concept) (pp. 151-167). Gottingen: Hogrefe.

Schüler, J., Sheldon, K. M., \& Fröhlich, S. M. (2010). Implicit need for achievement moderates the relationship between competence need satisfaction and subsequent motivation. Journal of Research in Personality, 44(1), 1-12. doi:10.1016/j.jrp.2009.09.002

Schultheiss, O., \& Brunstein, J. C. (2001). Assessment of implicit motives with a research version of the TAT picture profiles gender differences and relations to other personality measures. J Pers Assess, 77(1), 71-86.

Schultheiss, O., \& Brunstein, J. C. (2010). Implicit Motives (O. C. Schultheiss \& J. C. Brunstein Eds.). New York: Oxford.

Schultheiss, O., \& Kollner, M. G. (2014). Implicit motives and the development of competencies: A virtuous-circle model of motive-driven learning. In R. Pekrun \& L. Linnenbrink-Garcia (Eds.), Educational Psychology Handbook Series (pp. 73-95). New York: Routledge, Taylor Francis.

Schultheiss, O., \& Schultheiss, M. (2014). Implicit Motive Profile Analysis: An If-Then Contingency Approach to the Picture-Story Exercise. Social and Personality Psychology Compass, 8, 1-16. doi:10.1111/spc3.12082

Schultheiss, O., Wiemers, U. S., \& Wolf, O. T. (2014). Implicit need for achievement predicts attenuated cortisol responses to difficult tasks. Journal of Research in Personality, 48, 84-92. doi:10.1016/j.jrp.2013.10.004

Shan, P., Song, M., \& Ju, X. (2016). Entrepreneurial orientation and performance: Is innovation speed a missing link?. Journal of Business Research, 69(2), 683-690. doi:10.1016/j.jbusres.2015.08.032

Shane, S., Locke, E. A., \& Collins, C. J. (2003). Entrepreneurial motivation. Human Resource Management Review, 13(2), 257-279. doi:10.1016/s1053-4822(03)00017-2

Shane, S., \& Venkataraman, S. (2000). The promise of entrepreneurship as a field of research. The Academy of Management Review, 25(1), 217.

Shrader, R. C., Oviatt, B. M., \& McDougall, P. P. (2000). How new ventures exploit trade-offs among international risk factors: Lesson for the accelerated internationalization of the 21st century. Academy of Management Journal, 43(6), 1227.

Sitkin, S. B., \& Weingart, L. R. (1995). Determinants of risky decision-making behavior: A test of mediating role of risk perception and propensity. Academy of Management Journal, 38(6), 1573-1592.

Slabbinck, H., De Houwer, J., \& Van Kenhove, P. (2011). A pictorial attitude IAT as a measure of implicit motives. European Journal of Personality, 25(1), 76-86. doi:10.1002/per.778 
Slabbinck, H., van Witteloostuijn, A., Vanderstraeten, J., Hermans, J., Dejardin, M., \& Ramdani, D. (2018). The added value of implicit motives for management research development and first validation of a Brief Implicit Association Test (BIAT) for the measurement of implicit motives. PLOS One( In Press).

Spangler, W. D. (1992). Validity of Questionaire and TAT Measures of Need for Achievement. Psychological Bulletin, 112(1), 140-154.

Stewart Jr, W. H., Watson, W. E., Carland, J. C., \& Carland, J. W. (1999). A proclivity for entrepreneurship: A comparison of entrepreneurs, small business owners, and corporate managers. Journal of Business venturing, 14(2), 189-214.

Tambunan, T. (2007). Trade and Investment Liberalization Effects on SME Development: A Literature Review and a Case Study of Indonesia ESCAP, Towards coherent policy frameworks: understanding trade and investment linkages - A study by the Asia-Pacific Research and Training Network on Trade (Vol. 42, pp. 117-162). New York: United Nations.

Terjesen, S., Hessels, J., \& Li, D. (2016). Comparative International Entrepreneurship. Journal of Management, 42(1), 299-344. doi:10.1177/0149206313486259

Touhey, J. C., \& Villemez, W. J. (1975). Need achievement and risk-taking preference: A clarification. Journal of Personality and Social Psychology, 32(4), 713-719. doi:10.1037/00223514.32.4.713

Unger, J. M., Rauch, A., Frese, M., \& Rosenbusch, N. (2011). Human capital and entrepreneurial success: A meta-analytical review. Journal of Business venturing, 26(3), 341-358. doi:10.1016/j.jbusvent.2009.09.004

Unger, J. M., Rauch, A., Weis, S. E., \& Frese, M. (2015). Biology (prenatal testosterone), psychology (achievement need) and entrepreneurial impact. Journal of Business Venturing Insights, 4, 1-5.

Weinberger, J., \& McClelland, D. C. (1990). Cognitive versus traditional motivational models: Irreconcilable or Complementary? In E. Higgins \& R. M. Sorrentino (Eds.), Handbook of Motivation and Cognition (pp. 562-597). New York: Guilford Press.

Welch, L. S., \& Luostarinen, R. (1988). Internationalization: Evolution of a Concept. Journal of General Management, 14(2), 34-55. doi:10.1177/030630708801400203

Westhead, P., Ucbasaran, D., \& Wright, M. (2005). Decisions, actions, and performance: Do novice, serial, and portfolio entrepreneurs differ? Journal of Small Business Management, 43(4), 393417.

Westhead, P., Wright, M., \& Ucbasaran, D. (2001). The internationalization of new and small firms A resource based view. Journal of Business venturing, 16, 333-358.

Wiedersheim-Paul, F., Olson, H. C., \& Welch, L. S. (1978). Pre-export activity: The first step in internationalization. Journal of International Business Studies, 9(1), 47-58.

Wiklund, J., \& Shepherd, D. (2003). Knowledge-based resources, entrepreneurial orientation, and the performance of small and medium-sized businesses. Strategic Management Journal, 24(13), 1307.

Winter, D. G. (2010). Why achievement motivation predicts success in business but failure in politics: the importance of personal control. J Pers, 78(6), 1637-1667. doi:10.1111/j.14676494.2010.00665.x

Winter, D. G., John, O. P., Stewart, A. J., Klohnen, E. C., \& Duncan, L. E. (1998). Traits and motives: Toward an integration of two traditions in personality research. Psychological Review, 105(2), 230.

Wooldridge, J. M. (2005). Fixed-Effects and Related Estimators for Correlated Random-Coefficient and Treatment-Effect Panel Data Models. The Review of Economics and Statistics, 87(2), 385-390.

World-Bank. (2018). Indonesia Economic Quarterly: Strengthening Competitiveness. Retrieved from https://www.worldbank.org/en/country/indonesia/publication/indonesia-economic-quarterlydecember-2018

WTO. (2016). World Trade Reports 2016 [Press release]

Yamakawa, Y., Peng, M. W., \& Deeds, D. L. (2008). What drives new ventures to internationalize from emerging to developed economies? Entrepreneurship Theory and Practice(January), 59-82.

Young, S., Hamill, J., Wheeler, C., \& Davies, R. (1989). International market entry and development. Englewood Cliffs: Prentice-Hall. 
Zhou, C. (2019). Effects of ownership structure on the relationship between multinationality and downside risk. Cross Cultural \& Strategic Management, 26(3), 401-421. doi:10.1108/ccsm-102018-0172 